\title{
Long Wars and the Constitution
}

\author{
Stephen M. Griffin ${ }^{1}$
}

\section{Introduction}

In the aftermath of the terrorist attacks of September 11, 2001, the American constitutional system was shaken by a series of controversies arising out of the aggressive response of the Bush administration. Prominent among these were furious and deeply felt disputes over the use of torture in interrogation, the treatment of detainees, especially at Guantanamo Bay, and domestic surveillance. The Bush administration came under heavy criticism not only for actions initially taken in secret and unauthorized by Congress, but for the way it led the nation into the authorized war against Iraq in 2003. Many Americans believed that the war had been foisted on the public in a deceptive way without adequate consideration of its costs. As a result of these controversies, President George W. Bush was only the latest in a long line of chief executives accused of acting as an "imperial" president.

The advent of the Obama administration did not lead to a stilling of the waters. To an extent surprising to his supporters, President Barack Obama did not break decisively with all of the controversial policies of the Bush administration. ${ }^{2}$ This suggested a factor common to these administrations was at work. The controversies that plagued the Bush administration and the unwillingness of the Obama administration to change those policies were the latest examples of a long chain of constitutional difficulties connected with the unilateral exercise of presidential power in foreign affairs and, more specifically, the use of presidential power to wage war. 
Controversies over the use of executive power have existed throughout American history. But they took on a completely new dimension following the enormous expansion in the capacities of government necessary to prevail in World War II and the Cold War. Seen in this light, the deeply problematic aspects of the Bush administration's "war on terror" belong to a family of constitutional crises that include Watergate in the Nixon administration and the Irancontra affair in the Reagan administration. These crises are part of a pattern of recurrent policy disasters and constitutional problems linked to the war power that run back to the Truman administration and include both covert and overt military operations such as the Bay of Pigs and the Vietnam War.

Scholars have had difficulty analyzing this recurrent pattern, in part because of the influence of persuasive, yet misleading narratives such as the "imperial presidency." While presidents have not been blameless in their exercise of power in foreign affairs, neither have they been alone in making decisions or operating entirely outside the Constitution. Criticizing presidents as individuals gone haywire ignores that they have had significant, even sometimes overwhelming, political support for actions that from a constitutional point of view are quite dubious. It further ignores that they have plausibly seen themselves as chiefly responsible for advancing the foreign policy and protecting the national security of the United States. ${ }^{3}$

Americans like to think of their constitutional system as stable and resistant to formal change through amendment. Somewhat paradoxically, they also believe in the "living Constitution," a document that has adapted successfully to changing circumstances. The clashing character of these beliefs has been especially evident in the debate over the use of executive power in foreign affairs. "Presidentialists" argue that increased executive power after World War II was a reasonable alteration of the constitutional system in light of the new global 
responsibilities and hegemonic status of the U.S. "Congressionalist" opponents of this perspective cite the original eighteenth-century constitutional arrangements as their touchstone in defending the traditional powers of Congress. Common to both positions is the assumption that regardless of the degree of practical changes in the responsibilities of government, the Constitution was adequate to the challenge of the post-World War II era.

We can make better progress if we reject this assumption. This is an unfamiliar path for analysis, but one better able to cope with the complex relationship between the reality of changed circumstances and a relatively fixed text and set of traditions. Since the United States assumed a position of global leadership and responsibility after World War II, serious tensions have plagued our constitutional system. They are connected by the near-total reliance on executive power to defend national security.

Relative to the popular yet opposed narratives of the imperial presidency and executive triumphalism offered by congressionalists and presidentialists respectively, the argument I develop in this book is complex and cuts across the standard lines of the war powers debate. With presidentialists, I agree that the new global responsibilities of the United States necessitated a significant alteration to the constitutional order. Against presidentialists, I contend that the transition was anything but a smooth adaptation and was the source of severe and ongoing problems, not only within the constitutional order, but with respect to policymaking in foreign affairs and national security. With congressionalists, I agree that post-1945 presidents have acted against the eighteenth-century meaning of the Constitution and sometimes abused their power. Against congressionalists, I contend that the historical meaning of the war-making provisions of the Constitution could not be implemented in the post-1945 context, at least not 
without a formal overhaul of the separation of powers, especially of the structure of Congress, to a degree that has never been contemplated.

So my purpose in this book is not so much to contribute to the still-ongoing war powers debate as it is to reconceive it and change our perspective on what it should be about. Put another way, I offer a novel internal critique of the presidentialist position rather than adjudicating every point at issue in the debate. Presidentialists argue that executive leadership in foreign affairs is not only good policy, but is justified by the text and eighteenth-century history of the Constitution, as well as by subsequent practice. While I accept this position in its broad outlines, I insist on a key reservation. War is different. It is marked as such not only by legal authorities that all parties acknowledge as relevant to the war powers controversy, but by the actual practice of American diplomacy. While historical practice is a source of evidence that presidentialists have claimed for their own, it in fact supports the vital qualification that among the tools of diplomacy and national security strategy, war is special. The original constitutional order, preserved in key respects through the decades until the advent of the Cold War, makes approval by Congress obligatory before the nation goes to war. This order encouraged interbranch deliberation by requiring presidents to run the risk that their proposals for war would be rejected. In the post-1945 period, the unthinking extension of the position that the executive must lead in foreign affairs to the very different situation presented by decisions for war has destabilized the constitutional system and deranged policymaking.

In understanding the differences between the Cold War and previous periods of military conflict, we must consider all three dimensions of executive war making that were prominent after 1945. The Cold War featured new ways of war making in addition to conventional war. For example, covert wars involved paramilitary forces recruited from other countries. These 
forces were capable of mounting significant military operations, whether considered technically "covert" or not. Likewise, we should not overlook nuclear weapons. The presence of such destructive weapons strongly influenced military doctrine for fighting conventional wars. Perhaps more important, all presidents in the post-World War II period were required to come to grips with their responsibility for ordering U.S. forces to launch a strike that might kill hundreds of millions of people and render large areas of the globe uninhabitable.

One main theme of this book is that the Constitution can influence policy even when it is not enforced by the courts. War powers are an especially timely and relevant example of this phenomenon, which is still too little acknowledged by lawyers and legal academics. The Constitution could not constrain or empower government until it was implemented within an institutional structure which I call a "constitutional order." A succession of constitutional orders has enabled government to function effectively in the United States from the eighteenth century onward. War powers, however, have had a unique history. The Constitution was written to reflect the premise that the nation could go to war only through the meaningful deliberation and consent of the legislative and executive branches of government. A war undertaken solely by one branch would thus risk policy catastrophe. This is what has occurred all too frequently since 1945.

Critics of the imperial presidency have worried about the loss of civil liberties that has followed from the expansion of presidential power. Although I do not wish to minimize the violations of constitutional rights that did occur in the Cold War and after, our chief concern should be the consequences of overthrowing the policymaking process for war established by the Constitution. In particular, what I call the "cycle of accountability" that turns between the executive and legislative branches has not properly operated with respect to foreign affairs after 
1945. The cycle is a handy way of capturing what occurs when ordinary interbranch interaction is extended over time. Once a cycle is created, each branch knows that its decisions will be reviewed by the other. A pattern of mutual testing and deliberation results. Having a cycle of accountability means there is the potential to learn from mistakes. The cycle is an ongoing institutional practice in which both branches are held accountable.

Why is the post-1945 context so powerfully relevant for us today? Many commentators have seen the new-style conflict that followed 9/11 as a "long war." 4 Surprisingly, the most outstanding example of a "long war" - the Cold War fought against the Soviet Union and its communist allies - has been relatively neglected in the vast commentary that surrounds $9 / 11$. Indeed, one of the striking characteristics of post-9/11 America has been the failure to engage with the Cold War as a way of understanding how presidential power in foreign affairs is exercised in the context of a lengthy indeterminate struggle. This is both odd and telling.

No one doubts that the origins of the contemporary constitutional order in foreign affairs and defense policy, sometimes called the "national security state," lie in the Cold War. Yet we have not been overwhelmed with comparisons to the Cold War since 9/11. The pattern among legal scholars has been to search for analogies to the "war on terror" in Lincoln's leadership in the Civil War or Roosevelt's decisions during World War II. ${ }^{5}$ While it is important to understand the constitutional order in which Roosevelt operated, especially prior to Pearl Harbor, that order underwent a major transformation after 1945. The post-1945 constitutional order with respect to national security established by President Truman at the beginning of the Cold War and the all-encompassing struggle against the perceived threat of communism form the most important baseline for understanding our post-9/11 constitutional and governmental reality. 
The constitutional order prior to Pearl Harbor did not have to cope with a strategy in foreign affairs that assumed American responsibility for global security, accompanying global military commitments, U.S. troops permanently stationed in foreign countries, intelligence agencies engaged in covert action, or nuclear weapons. Whereas prior to Pearl Harbor the U.S. was certainly engaged in world affairs as a naval power, it also adhered to a sharp distinction between war and peace and declarations or authorizations of war as integral elements of diplomacy. The Cold War constitutional order involved apprehension of an existential threat, a perceived danger from an appealing global ideology that mandated increased internal security, assertions that we had to stand ready to violate long-held values and beliefs, and enforced acceptance that we were in totally unique circumstances, never before seen in American history, involving an indefinite war against an implacable foreign enemy. If these elements seem familiar, as of course they should, I hope you will join me in wondering why scholars have not been probing the Cold War more assiduously for clues about the sources of our post-9/11 difficulties in foreign policy. ${ }^{6}$

While war powers are central to my argument, this book is more of an analytical history of presidential decisionmaking than a legal treatise and, apart from parts of chapters 1 and 2 , is not structured as a contribution to the war powers debate. As I stated earlier, I am not so much trying to contribute to the standard debate as I am attempting to reconceive it and change commonly accepted ideas of what the debate is about. In my view, the debate must be firmly grounded in an understanding of U.S. foreign policy and, at the same time, the special issues posed when the U.S. actually engages in a major war. Many people believe, for example, that important questions are at stake every single time the president orders the use of any sort of military force. By contrast, I closely analyze presidential decisionmaking concerning major wars 
and covert paramilitary actions in the context of U.S. foreign policy. While this presents some issues of definition, there is wide agreement on the most significant wars the U.S. has fought since 1945 - Korea, Vietnam, the 1991 Gulf War, Afghanistan and Iraq. Although I also discuss major covert actions involving the threat of war, such as those against Cuba and Nicaragua, and the deployment of nuclear weapons, these major military conflicts just noted are my central concern. ${ }^{7}$ The first two wars caused most of the casualties suffered by our armed forces since 1945 and have been solemnized with memorials on the Mall, one of our nation's most honored spaces. Such wars past and present deserve our special concern, respect and attention.

Nevertheless, the fact that I cross the path of the war powers debate demands some further comment. The standard debate has been ongoing at least since the Vietnam War became controversial in the mid-1960s. Yet the controversy is unusual in some respects. Consider that there is no scholarship on the history of the war powers debate as such. Was Vietnam in fact the origin of the debate and its vast and intricate web of argumentation? Consider also that there is no scholarly history of key elements of the debate such as the 1973 War Powers Resolution. It is as if the debate has always been with us, beyond history. Indeed, it is widely believed that the controversy flows from a power struggle between the executive and legislative branches that began in the early republic. One of my key findings is that this sense of a timeless controversy is an artifact of the Cold War itself, something largely promoted by presidentialists. The war powers debate did not exist in its contemporary form, including the broad claims made by post1945 presidents, until the advent of the Cold War in the Truman administration. This is a strong claim, yet one amply supported by a detailed consideration of diplomatic history.

In order to demonstrate this contention and promote clarity with respect to a debate many legal scholars regard as a stalemate, I have gone to some lengths to situate the debate in the Cold 
War. This naturally suggests a focus on the distinctive assertions of power that presidents made in this period. Over time, however, the academic debate has focused more on the claims of scholars than of presidents. While this is not entirely surprising, what is startling is how badly many prominent scholars have misunderstood the maximal character of those presidential claims. In turn, because of this misunderstanding, the clarity with which the evidence from the founding period speaks to the contemporary war powers debate has not been appreciated fully. Beginning with Truman, nearly all post-1945 presidents have claimed the unilateral power under Article II to initiate war, "real" war, full-scale war. The underappreciated crux of the war powers debate is that while this bold presidential claim is inconsistent with the historical meaning of the Constitution, it has an eminently defensible policy rationale.

While I am not sympathetic to this unilateral presidential claim, the standard congressionalist critique is simply too narrow. Considered from the perspective of the executive branch, this claim does not appear extraordinary because it is encapsulated in a larger perspective, which many have found persuasive, in which military force is one tool among others in advancing the foreign policy and preserving the national security of the United States. By concentrating on whether every presidential military action is specifically authorized, the congressionalist critique has missed the real problem - the absence of interbranch deliberation over time on matters of foreign policy and national security strategy - that is, the lack of a cycle of accountability.

By contending that presidential war powers claims should be understood within the framework of American diplomacy, I urge a bit more sympathy for presidents than congressionalists have managed to display in the war powers debate. The presidentialist position 
cannot be understood and evaluated appropriately unless we have a firm grasp on the situation the executive branch faced at the beginning of the Cold War.

In order to carry out this contextual task, we must expand the frame of the war powers debate, considering insights that constitutional scholars have generally bypassed from primary and secondary sources relating to diplomatic history and presidential decision making in foreign policy. This book is thus based primarily on a comprehensive survey of the diplomatic and presidential history of the post-World War II period. Inevitably, my sources will not satisfy some historians who expect familiarity with the latest specialized studies. However, my argument is based on a more thorough assessment of the relevant historical literature, along with some key collections of primary sources, than any previous work on war powers with respect to this critical period of American history.

The plan of the book is as follows. Chapters 1 and 2 create the framework that guides the discussion in the rest of the book. Chapter 1 introduces the concept of a constitutional order and describes the order of the early republic with respect to war and foreign affairs. Chapters 1 and 2 contrast this pre-Pearl Harbor constitutional order with the post-1945 constitutional order founded by President Truman, his advisers, key members of Congress and the foreign policy elite in the early Cold War. Chapters 1 and 2 also establish the historical context necessary to evaluate the arguments in the standard war powers debate. Chapter 2 shows how Truman created the presidential power to initiate war, a key element of the post-1945 constitutional order, when he made the decision in 1950 to intervene in Korea. It concludes by summarizing the elements of the post-1945 constitutional order. 
The next four chapters provide an extended analysis of the problems and tensions encountered as policymakers attempted to work within the inherently flawed structure of the post-1945 constitutional order amid three different arenas for war making: conventional, covert, and nuclear. Chapter 3 discusses the Eisenhower and Kennedy administrations and describes Eisenhower's way of war and the increasing use of covert war in both administrations, culminating in the 1962 Cuban missile crisis. Chapter 4 describes the crisis of the post-1945 constitutional order in the Johnson and Nixon administrations, linking the Vietnam War with Watergate.

After Vietnam there was a break in the continuity of the Cold War in that the political parties took different paths with respect to war and foreign affairs. While Democrats increasingly doubted the verities of the Cold War, an attitude reflected in their support of Nixon's policy of détente with the Soviet Union, Republicans bypassed the trauma of Vietnam in favor of renewing a commitment to the Cold War. Chapter 5 thus begins with an analysis of where matters stood after Vietnam and follows the path of the Ford, Carter, Reagan, and Bush I administrations as they attempted to cope with a post-Vietnam environment in which the post1945 constitutional order was nonetheless still dominant. Chapter 6 carries the post-Vietnam discussion through the Clinton and Bush II administrations, especially in light of the challenges posed by 9/11. Throughout these chapters I focus on demonstrating the recurrent pattern of policy dysfunction and constitutional crisis caused by the friction between the original constitutional order and the post-1945 order.

In chapter 7 I examine whether it would be possible to build a new constitutional order to deal with the problems caused by the jerry-built structure of the post-1945 order. I do this in two main stages. I first summarize how to reconceive the war powers debate by reviewing what the 
debate should be about. After commenting on how the Obama administration fits into the post1945 constitutional order, I then move to a consideration of how altering the structure of Congress is a necessary precondition for addressing our war powers troubles.

In all candor I should say that proposing solutions is secondary to this book's purpose. Why is this justifiable? While I like proposing solutions as much as the next legal academic, it bears emphasis that the solutions offered in faculty lounges tend to assume a judicial deus ex machina that is not available for war powers. The most important task with respect to war powers is simply to understand the position we are in. Thus my primary purpose is not to propose solutions to our war powers difficulties but rather to change our perspective on both where the problem lies and how to move forward.

Ultimately, I aim to provide the missing connections between the exercise of presidential power in foreign affairs and a continuing series of policy disasters and constitutional crises. This book connects the dots with respect to the Constitution and national security and explains a recurrent and, indeed, tragic pattern of interbranch relations and presidential decisions. 


\section{Long Wars and the Constitution}

\section{Detailed Table of Contents}

Introduction

Chapter 1 - War Powers and Constitutional Change

- The Importance of Constitutional Orders

- The Original Constitutional Order

- Foreign Affairs and War in the Early Republic

- Reconceiving the War Powers Debate

- The Significance of Authorized Wars

Chapter 2 - Truman and the Post-1945 Constitutional Order

- Before Pearl Harbor

- Roosevelt's Prewar Diplomacy

- Constructing a New Constitutional Order

- The Korea Decision: Creating the Presidential Power to Initiate War

- The Power to Initiate War: Continuity or Change?

- Truman and the "Imperial Presidency"

- The Post-1945 Constitutional Order and Its Discontents

Chapter 3 - War and the National Security State

- The National Security Act and Covert War

- Eisenhower's Way of War

- Will Cuba Destroy the World?

- The Strains of War and the Public Sphere 
Chapter 4 - Vietnam and Watergate: The Post-1945 Constitutional Order in Crisis

- The Limited Relevance of the Tonkin Gulf Resolution

- Deciding for War Without Congress

- The Strains of War and Internal Security

- Watergate as a Cold War Constitutional Crisis

- Ending the War Without Congress

Chapter 5 - The Constitutional Order in the Post-Vietnam Era

- Taking Stock of the Cold War

- Nuclear Weapons and the Reagan Presidency

- The War Powers Resolution

- Implementing the WPR: Politics, Policy, and the Constitution

- The Gulf War and the Persistence of the Cold War Order

- Covert War and the Iran-Contra Affair

- The Arrival of the Exclusive Presidency

Chapter 6 - The 9/11 Wars and the Presidency

- The End of the Cold War and the Persistence of the Post-1945 Constitutional Order

- War Powers After the Cold War

- After 9/11: The Role of History and Memory

- 9/11 and the Post-1945 Constitutional Order

- Afghanistan and Iraq: The Executive Branch at War

Chapter 7 - A New Constitutional Order?

- What the War Powers Debate Should be About

- From Vietnam to Iraq

- Obama's Way of War

- Starting the Cycle of Accountability

- The Difference Parties Make

- Beyond the Imperial (Triumphal) Presidency

- Writing the Constitution into History 
${ }^{1}$ Rutledge C. Clement Professor in Constitutional Law, Tulane Law School. This book is forthcoming from Harvard University Press in June 2013, all rights reserved.

${ }^{2}$ This is a major theme in Jack Goldsmith, Power and Constraint: The Accountable Presidency after 9/11 3-22 (2012).

${ }^{3}$ Id. at $23-29$.

${ }^{4}$ See, e.g., Benjamin Wittes, Law and the Long War (2008).

${ }^{5}$ See, e.g., Harold H. Bruff, Bad Advice: Bush's Lawyers in the War on Terror (2009); William N. Eskridge Jr. and John Ferejohn, A Republic of Statutes: The New American Constitution 389-92 (2010); Jack Goldsmith, The Terror Presidency (2007).

${ }^{6}$ For collections that do focus on the Cold War, see Mary L. Dudziak ed., September 11 in History: A Watershed Moment? (2003); Ellen Schrecker ed., Cold War Triumphalism: The Misuse of History After the Fall of Communism (2004). See also Mary L. Dudziak, War Time: An Idea, Its History, Its Consequences (2012).

${ }^{7}$ This approach differs from the methodology followed in two notable recent studies by political scientists. See William G. Howell and Jon C. Pevehouse, While Dangers Gather: Congressional Checks on Presidential War Powers (2007); Douglas L. Kriner, After the Rubicon: Congress, Presidents, and the Politics of Waging War (2010). These studies employ a dataset that, at least originally, was limited to political uses of military force short of war. See Howell and Pevehouse at 53-54. The original dataset thus excluded Korea and Vietnam because they were wars involving sustained hostilities. See Barry Blechman and Stephen Kaplan, Force without War: U.S. Armed Forces as a Political Instrument 12-16 (1978). Minor uses of the military, such as force deployments without hostilities, have not caused the sort of systemic problems with the constitutional order which is my concern in this book. It should be noted, however, that Kriner's study includes Korea and Vietnam. See Kriner at 89-91. 